\title{
INDIGENOUS SELF-DETERMINATION: THE ROOT OF STATE RESISTANCE
}

\author{
Sarah Sargent ${ }^{*}$ and Graham Melling ${ }^{\#}$
}

\section{INTRODUCTION}

States have long expressed some resistance towards granting the right of self-determination to identifiable groups of people within their boundaries. This includes the granting of the right to minorities and to indigenous groups. One of the ways in which this reluctance reveals itself is in States' resistance to the granting of recognition of "peoples" to certain groups. States, it would seem, draw the erroneous conclusion that recognition of groups as "peoples" under international law will inexorably lead to such "peoples" asserting a right to self-determination and with that an unfettered ability to secede from the state. However states' fear of indigenous secession has no realistic basis. Yet states continually resist the idea of indigenous self-determination.

Why has such an interpretation taken hold as an accepted normative doctrine of international law? States, apparently fearing for their territorial integrity (and perhaps for the natural and other resources within certain land), resist recognising groups as "peoples". ${ }^{1}$ As this article discusses, however, the fear that indigenous groups would seek secession from the state upon being recognised as "peoples" is groundless. To understand the recognition of a group as "peoples" and the principle of self-determination in this manner is fundamentally inaccurate. This article posits that states fear of losing territorial integrity through indigenous secession is not at the heart of state resistance to indigenous self-determination. Rather, the resistance of states to indigenous self-determination is located in another source - modern state identity as liberal states.

Indigenous self-determination is at odds with in particular Jacobin forms of liberal statehood in particular ${ }^{2}$ and arguably, that is the real root of state

\footnotetext{
* Dr Sarah Sargent, Lecturer at Law, University of Buckingham.

\# Dr Graham Melling, Lecturer at Law, University of Buckingham.

1 The recognition of groups as "peoples" in international law has occurred a limited number of times since 1945 .

${ }^{2}$ A Jacobin form of liberal statehood is reflective of how a state does with plurality among its members. As discussed below at footnotes 64 and 65 and accompanying text, a Jacobin form of statehood emphasises loyalty and identification with the state rather than with ethnic or other groups within the state. W Safran explains that "Jacobin doctrine...emphasized a highly centralized state and rejected both
} 


\section{INDIGENOUS SELF-DETERMINATION}

resistance not only to indigenous self-determination but to all indigenous rights norms that are seen as a threat to liberal statehood. State resistance to the principle of self-determination in the United Nations Declaration on Indigenous Rights (UNDRIP) ${ }^{3}$ reveals on-going state unease over granting collective "hard" rights under international law. Even though the recognition of the right of self-determination within the UNDRIP gives rise to a "hard" right, such recognition is as much symbolic as giving rise to concrete practical outcomes, such as secession. International law as yet has not extended that far and for practical considerations is unlikely to do so. Accommodation by states, however, of indigenous rights means a reformulation of state identity away from modern Jacobin liberalism - something states view as deeply threatening. Therefore it is unlikely to occur.

\section{STATE RESISTANCE TO INDIGENOUS SELF- DETERMINATION}

There is a widespread view that sees any international recognition of a particular group as a "peoples" brings with it an immediate access to all of the actions embodied within the principle of self-determination. A group with access to self-determination is seen as having an immediate and incontestable right to secede from the state to create its own independent state. State resistance to indigenous self-determination is often presented as being lodged in this commonly held, but inaccurate, perception of the normative content of the principle of self-determination. ${ }^{4}$

institutional and ethnocultural pluralism." W Safran "Pluralism and Multiculturalism in France: Post Jacobin Transformations" (2003) 118(3) Political Science Quarterly 437 at 438.

${ }^{3}$ The United Nations Declaration on the Rights of Indigenous Peoples was approved by the United Nations General Assembly on 13 September 2007, A/Res/61/295, available at http://daccess-ddsny.un.org/doc/UNDOC/GEN/N06/512/07/PDF/N0651207.pdf?OpenElement. Accessed $1^{\text {st }}$ September 2012.

${ }^{4} \mathrm{M}$ Davis comments: 'Self-determination for indigenous peoples was still viewed by many states as synonymous with decolonisation and a threat to the territorial integrity and sovereignty of states.' She refers to this interpretation of the principle of selfdetermination as 'the dominant decolonisation construct.' M Davis "Indigenous Struggles in Standard Setting: The United Nations Declaration on the Rights of Indigenous Peoples" (2008) 9 Melbourne Journal of International Law 1 at 21. See also J Castellino "Territorial Integrity and the 'Right' to Self-Determination: An Examination of the Conceptual Tools" (2008) 33(2) Brooklyn Journal of International Law 499 at 511, commenting: "The General Assembly explained that selfdetermination was a decolonization process..." and further: "Many classify the right to self-determination as a norm of jus cogens, even though the phrasing of the [Friendly 
State expression of resistance to indigenous self-determination through opposition to the UNDRIP is only the latest in a consistent chain of events where states resist the merest reference to indigenous groups as "peoples". There is nothing new or unique in state positionality on the UNDRIP and its self-determination content. Throughout the indigenous rights movement in the international community, states have been reluctant to recognise indigenous groups as "peoples". This reluctance has also been expressed in state positions regarding minority groups and self-determination. ${ }^{5}$

This was evident in state resistance to the idea of indigenous groups being referenced as "peoples" during the revisions of International Labour Convention 107. ILO Convention 107 was criticised as being too assimilationist in its content and in need of revision to reflect the contemporary thinking that assimilation as an appropriate policy for states to pursue. ${ }^{6}$ The revisions that were made to ILO Convention No 107 resulted in a new convention, ILO Convention NO 169 in $1989 .{ }^{7}$ Gone were the provisions that were seen to present a very paternalistic and assimilationist approach towards indigenous rights. The ILO Convention No 169 instead presented an entirely new approach towards indigenous peoples in international law. Lee Swepston comments that ILO Convention No 169:

"...adopts an attitude of respect for the cultures and ways of life of indigenous and tribal peoples. It presumes their right to continued existence and to development along lines they themselves wish. The

Declaration] itself clearly limits application of the doctrine to decolonization...", at 512. See also discussion on the drafting of the United Nations Declaration on the Rights of Indigenous Peoples at section 3 below. See also S Wiessner "Indigenous Sovereignty: A Reassessment in Light of the UN Declaration on the Rights of Indigenous Peoples" (2008) 41 Vanderbilt Journal of Transnational Law 1141 at 1159-1162 on how state fears of indigenous secession through self-determination delayed an approval vote in the United Nations General Assembly. See also S J Anaya, Indigenous Peoples in International Law $\left(2^{\text {nd }}\right.$ edition, Oxford University Press, 2004) pp 59-60, commenting that in relation to ILO Convention No 169, "State governments, however, resisted, use of the term peoples because of its association with the term self-determination.....which in turn has been associated with a right of independent statehood." At 60, emphasis in the original.

${ }^{5}$ For a general discussion see S Sargent "Transnational Networks and United Nations Human Rights Structural Change: the Future of Minority and Indigenous Rights" (2012) 16(1) The International Journal of Human Rights 123 at 136-139.

${ }^{6}$ Anaya, above n 4, pp 58-59.

7 Ibid, p 59. See also L Swepston "A New Step in the International Law on Indigenous and Tribal Peoples: ILO Convention No 160 of 1989" (1990) 3(15) Oklahoma City University Law Review 677 at 687-689. 


\section{INDIGENOUS SELF-DETERMINATION}

convention also provides...for the right of these peoples to be involved in the decision-making process as it affects them."

Yet, states remained very wary about a broader grant of international rights to indigenous groups. This is reflected in two ways. Firstly, the ILO Convention 169 is hard law-that is, it is binding upon states in contrast to the soft and non-binding law of the UNDRIP. This may account for the reluctance of states to ratify this instrument, despite its high profile in international law. ${ }^{9}$ States remain wary of agreeing to indigenous rights that can be classified as "hard rights." 10 a binding international law instrument would certainly fall into the class of "hard rights." Secondly, despite a reference to indigenous groups as "peoples" within ILO 169, that designation is given with a strong disclaimer. Preambular language makes reference to "indigenous peoples" and to "indigenous and tribal peoples" in several places. ${ }^{11}$ The body of the instrument itself is quick to dispel that this is in any way a grant of recognition as "peoples" under international law. Article 1(3) unequivocally states:

"The use of the term peoples in this Convention shall not be construed as having any implications as regards the rights which may attach to the term under international law." 12

The same resistance towards the use of the word "peoples" arose in debates over the naming of the newly created United Nations Permanent Forum on Indigenous Issues (UNPFII). ${ }^{13}$ The creation of the forum itself was seen as a victory. The forum was permanent in nature and was the first UN

\footnotetext{
${ }^{8}$ Ibid, 690.

${ }^{9}$ Only 20 number of states have ratified this instrument as of 1 September 2012. http://www.ilo.org/indigenous/Conventions/no169/lang--en/index.htm. Accessed on 1 st September 2012.

${ }^{10} \mathrm{~S}$ Lightfoot argues that indigenous rights and the compliance of states with these rights can be analysed in part by dividing rights into "hard" and "soft" rights, with states more likely to comply with those rights deemed as "soft." She lists "hard rights" as including "land rights and self-determination" while soft rights include "language, culture, religion..." S Lightfoot, "Emerging International Indigenous Rights Norms and 'Over-Compliance' in New Zealand and Canada" (2010) 62(1) Political Science 84 at 104.

${ }^{11}$ International Labour Organisation Convention No 169.

${ }^{12}$ International Labour Organisation Convention No 169, Article 1(3).

${ }^{13}$ Sargent, above n 5, 123,139.
} 
forum to be specifically focused on indigenous issues. ${ }^{14}$ It took nearly 10 years for the forum to be created from its first recommendation in 1993 to official recognition by UN Resolution in $2002 .{ }^{15}$ Prior to this however a disagreement arose over the name. ${ }^{16}$ But opponents of indigenous selfdetermination opposed such a designation of a forum for indigenous "peoples", fearing that even referencing indigenous groups as "peoples" in a forum would be an avenue for indigenous groups to lay claim to the right to self-determination. ${ }^{17}$

Yet again state resistance to the use of the word "peoples" in connection with indigenous groups appeared in debates over what to name the United Nations Decades for indigenous groups. States resisted the use of the word "peoples", and so the two decades became known as the Decade of Indigenous People-but not as "Peoples". ${ }^{18}$ The inclusion or not of the final "s" on the word may appear to be semantic trifling. But it is far more than that. That states oppose the use of the word outside legal instruments - and stand against its use in the naming of a forum and in United Nations recognition of events - speaks to the very deep-seated nature of state positions on any linkage between "indigenous" and "peoples."

Yet, as discussed in section 4 of this article, the unrealistic grounding of the state fear of indigenous cessation through self-determination must be examined. States consistently and relentlessly resist the linkage of "indigenous" and "peoples" - for reasons that are no more than a smokescreen covering deeper and unstated fears.

\section{THE DEVELOPMENT OF THE UNITED NATIONS DECLARATION ON THE RIGHTS OF INDIGENOUS PEOPLES}

Drafting of the United Nations Declaration on the Rights of Indigenous Peoples was a process which was long and drawn out over more than twenty years. Both states and indigenous groups contributed to the content of the document. The content is notable in that no definition of "indigenous" is

\footnotetext{
${ }^{14}$ Ibid, p 139. See also Anaya, above n 4, pp 219-220; J Corntassel "Partnership in Action? Indigenous Political Mobilization and Co-optation During the First UN Indigenous Decade (1995-2004)" (2007) 29 Human Rights Quarterly 137 at 138, 148.

15 Anaya, above n 4, p 219-220; Corntassel, ibid, at 138, 148.

${ }^{16}$ Corntassel, above n 14, at 155.

${ }^{17} \mathrm{Ibid}$, at 155 .

${ }^{18} \mathrm{~S}$ Wiessner "Rights and Status of Indigenous Peoples: A Global Comparative and International Legal Analysis" (1999) 12 Harvard Human Rights Journal 57 at 101102.
} 


\section{INDIGENOUS SELF-DETERMINATION}

offered and, secondly, the instrument recognises indigenous groups as "peoples" with access accordingly to the principle of self-determination. These two issues in concert created and continue to create state resistance to indigenous rights at international law. The ILO Convention 169 contains some defining characteristics to set out what groups and individuals are covered by its provisions. ${ }^{19}$ Despite this inclusion, the Convention also makes clear that the idea of "self-identification" is the "fundamental criterion for determining the groups to which the provisions of this Convention apply". ${ }^{20}$

In an unexpected late development, as the draft Declaration was headed to a scheduled vote in the UN General Assembly, opposition to the content on the principle of self-determination was such that potential approval was in doubt. ${ }^{21}$ It was only after amendments to the Declaration clarifying that the self-determination of indigenous peoples did not permit secession from the state that the vote went forward on the floor of the General Assembly. ${ }^{22}$ The instrument was amended to include the language of now Article 46 that made clear that an exercise of self-determination by indigenous peoples would not harm the territorial integrity of states. ${ }^{23}$ In short, the right to self-determination provided for in Article 3 of the Declaration was tempered by the language of Article 46 to provide for "internal" self-determination - which gives rights more akin to self-governance and autonomy within the existing boundaries of a state.

As the last-minute flutter of activity on the Declaration's content shows, states fear the exercise by indigenous peoples of self-determination in any of its many guises. Accordingly States feared that if indigenous groups were given recognition in international law as "peoples" 24 and thus gained a claim

\footnotetext{
${ }^{19}$ Article 1(a) and (b).

${ }^{20}$ Article 1(2).

${ }^{21}$ Wiessner, above n 5, at 1141, 1159-1162; see also Sargent, above n 5, at 137.

${ }^{22}$ United Nations General Assembly, A/RES/61/295 13 September 2007.

http://daccess-dds-
}

ny.un.org/doc/UNDOC/GEN/N06/512/07/PDF/N0651207.pdf?OpenElement.

Accessed on $1^{\text {st }}$ September 2012.

${ }^{23}$ Article 46 in relevant part states:

"1. Nothing in this Declaration may be interpreted as implying for any State, people, group or person any right to engage in any activity or to perform any act contrary to the Charter of the United Nations or construed as authorizing or encouraging any action which would dismember or impair, totally or in part, the territorial integrity or political unity of sovereign and independent States."

${ }^{24}$ For instance, the International Labour Organisation Instrument 169 tempers its use of the word "peoples" in the instrument by explaining this use does not suggest access to the principle of self-determination. 
to a legitimate exercise of self-determination in accordance with the principle in the UN Charter ${ }^{25}$ and in the joint Article 1 of the International Covenant on Civil and Political Rights and the International Covenant on Economic, Social and Political Rights. ${ }^{26}$ Is this, however, a realistic fear of states? Whilst there are numerous statements that indigenous peoples do not seek secession from states that has not allayed state resistance to indigenous self-determination and concomitantly then to international law provisions for indigenous rights.

\section{INTERNAL AND EXTERNAL SELF-DETERMINATION}

The principle of self-determination is clearly established as an important principle of international law. It is given clear expression in Article 1(2) and 55 of the UN Charter; the Declaration on the Granting of Independence to Colonial Territories and Peoples; the International Covenant on Civil and Political Rights and the International Covenant on Economic Social and Cultural Rights, ${ }^{27}$ the 1970 Friendly Relations Declaration ${ }^{28}$ and the Organisation for Security and Co-operation in Europe's Helsinki Final Act. ${ }^{29}$

${ }^{25}$ Article 1(2) Charter of the United Nations.

${ }^{26}$ Article 1 International Covenant on Civil and Political Rights, 999 UNTS 171, GA Res 2200A (XXI), UN Doc A/6316 (Dec 16, 1966).

${ }^{27}$ See International Covenant on Civil and Political Rights Art. 1, 999 UNTS 171, GA Res 2200A (XXI), UN Doc A/6316 (Dec 16, 1966); International Covenant on Economic Social and Cultural Rights art. 1, 933 UNTS 3, GA Res 2200A (XXI), UN Doc A/6316 (Dec 16, 1966).

${ }^{28}$ Declaration on Principles of International Law Concerning Friendly Relations and Co-operation among States in accordance with the Charter of the United Nations GA Res 2625, Annex, 25 UN GAOR, Supp. (No 28), UN doc A/5217, 121 (1970).

29 The Final Act of the Conference on Security and Co-operation in Europe, $1^{\text {st }}$ August 1975, 14 I L M 1292 (Helsinki Declaration) This states:

"The participating States will respect the equal rights of peoples and their rights to self-determination, acting at all times in conformity with the purposes and principles of the Charter of the United Nations and the relevant norms of international law including those relating to territorial integrity of States.

By virtue of the principle of equal rights and self-determination of peoples, all peoples always have the right, in full freedom, to determine, when and as they wish, their internal and external political status, without external interference, and to pursue as they wish their political, economic, social and cultural development." 


\section{INDIGENOUS SELF-DETERMINATION}

Furthermore this right is firmly entrenched in customary international law. ${ }^{30}$ The first question to be addressed is, what does self-determination mean?

The 1970 Friendly Relations Declaration defined the right of selfdetermination as extending to "all peoples" and:

"By virtue of the principle of equal rights and self-determination of peoples enshrined in the Charter of the United Nations, all peoples have the right freely to determine, without external influence, their political status and to pursue their economic, social and cultural development, and every State has the duty to respect this right in accordance with the provisions of the Charter." ${ }^{\prime 1}$

Despite rhetoric to the contrary, there is no settled agreement on the meaning of self-determination. A good explanation of the meaning of selfdetermination is provided by Professor Susanna Mancini who suggests that self-determination "roughly" 32 equates to:

"the freedom for all peoples to decide their own political, economic and social regimes. It is, therefore, both a collective right of peoples to decide autonomously the course of their national life and to share power equitably, and a right of all individuals to participate fully in the political process." 33

Professor Mancini's definition provides a nuanced analysis of the concept of self-determination taking into account both the collective and individual nature of the idea of self-determination. For Professor Mancini the concept of self-determination recognises the "collective" in the sense of it providing a right for a group of "peoples" to self-determination and the "individual" in

${ }^{30}$ Western Sahara Case Advisory Opinion ICJ Rep 1975, 12, para. 56; J Vidmar "International Legal Responses to Kosovo's Declaration of Independence" (2009) 42 Vanderbilt Journal of Transnational Law 779 at 807; R McCorquodale "SelfDetermination: A Human Rights Approach" (1994) 43 International \& Comparative Law Quarterly 857 at 858.

${ }^{31}$ Declaration on Principles of International Law Concerning Friendly Relations and Co-operation among States in accordance with the Charter of the United Nations GA Res 2625, Annex, 25 UN GAOR, Supp. (No.28), UN doc. A/5217, 121 (1970). This definition was subsequently re-iterated in the Helsinki Final Act of 1975.

32 S Mancini "Rethinking the Boundaries of Democratic Secession: Liberalism, Nationalism, and the Right of Minorities to Self-Determination" (2008) 6 International Journal of Constitutional Law 553 at 554.

${ }^{33}$ Ibid. 
that the individual within the group of "peoples" has a right to participation in the collective right. With both facets facilitating equal and autonomous participation in political, economic and social regimes. Mancini's view is underpinned by the individual right to participate in the political process guaranteed to all "people" under Article 25 ICCPR. ${ }^{34}$ However, for the purposes of self-determination it is the collective right of a group that accounts for the doctrine. An individual whilst having his/her right to participation in the political process guaranteed under the ICCPR could not realistically claim a right to self-determination. However, the guaranteed individual rights of people contained in the ICCPR underpin the collective rights that are enforced by the doctrine of self-determination.

Initially the right of self-determination was applied in the colonial context becoming a legal norm which could override the related principles of sovereignty and territorial integrity. ${ }^{35}$ The process of decolonization led to the creation of over one hundred states with the principle of self-determination playing a central role. The importance of the principle of self-determination was highlighted in the International Court of Justice's important Namibia Opinion $^{36}$ in which the Court concluded:

"In the domain to which the present proceedings relate, the last fifty years... have brought important developments. These developments leave little doubt that the ultimate objective of the sacred trust was the self-determination and independence of the peoples concerned." 37

Outside the context of colonialism, however, there has been resistance to the suggestion that the right self-determination might have any application, in particular on the part of the emerging Third World and Eastern European states. Yet, despite such resistance the idea of the right of self-determination being applicable outside colonialism has been fostered by a number of international declarations and political instruments notwithstanding any resistance on the part of some states. Moreover, in 1988 the International Law Commission expressed the opinion that the principle of self-determination

\footnotetext{
${ }^{34}$ International Covenant on Civil and Political Rights art 1, 999 UNTS 171, GA Res 2200A (XXI), UN Doc A/6316 (Dec. 16, 1966).

${ }^{35}$ Declaration on the Granting of Independence to Colonial Territories and Peoples GA Res 1514 (XV). December 14, 1960. GAOR $15^{\text {th }}$ Sess, Supp 16, 66.

${ }^{36}$ Legal Consequences for States of the Continued Presence of South Africa in Namibia (South West Africa) notwithstanding Security Council Resolution 276 (1970) ICJ Rep 1971, 16.

${ }^{37}$ Ibid, 31 paragraph 53.
} 


\section{INDIGENOUS SELF-DETERMINATION}

was of universal application. ${ }^{38}$ Therefore, that international law recognises the right of all peoples to self-determination is a well-established principle of international law.

The normative meaning of self-determination has been split into two internal and external self-determination. Internal self-determination operates within the boundaries of existing states. In particular "as a right of the entire population of the State to determine its own political, economic and social destiny and to choose a representative government; and, equally, as a right of a defined part of the population, which has distinctive characteristics on the basis of race or ethnicity, to participate in the political life of the State, to be represented in its government and not to be discriminated against." ${ }^{39}$ External self-determination is an exercise that results in the secession of a group from the state, and the establishment of a new independent state. As discussed in the following section, the definition of self-determination ultimately approved in the United Nations Declaration on the Rights of Indigenous Peoples was that of internal self-determination. It is not often recognised in the context of discussions on indigenous rights that internal self-determination is not a concept unique to the Declaration or to indigenous rights.

\section{A RIGHT TO EXTERNAL SELF-DETERMINATION?}

International law and international practice has provided guidance with respect to self-determination. It constitutes a right of an entire population of a state to determine its own political and social destiny within a state or as a defined peoples which has distinctive characteristics on the basis of race or ethnicity, to participate in the political life of the State, to be represented in its government and not to be discriminated against. These rights are to be exercised within the State in which the population or the ethnic or indigenous

${ }^{38}$ M Shaw International Law (Cambridge University Press 2008) p 270; R Higgins Problems \& Process (Oxford: Clarendon Press, 1994) p 116; Yearbook of the ILC, 1988, vol II Part 2, 64: "The principle of self-determination, proclaimed in the Charter as a universal principle, had been applied mainly in eradicating colonialism, but there were other cases in which it had been and could and should be used. By not tying it exclusively to colonial contexts, it would be applied much more widely. In that connection, all members of the Commission believed that the principles of selfdetermination was of universal application."

${ }^{39}$ Accordance with International Law of the Unilateral Declaration of Independence in Respect of Kosovo (Request for Advisory Opinion) available at http://www.icjcij.org/docket/index.php?p1=3\&p2=4\&k=21\&case $=141 \&$ code $=k o s \& p 3=4$, Separate Opinion of Judge Yusuf, p 3 paragraph 9. 
group live, and thus constitute internal rights of self-determination. ${ }^{40}$ Where international law provides less coherent guidance is where a "peoples" wish to exercise a right of external self-determination. In more recent times minority groups within states have sought to claim a right to self-determination and that that self-determination entails secession. ${ }^{41}$ This is referred to as "external selfdetermination". ${ }^{42}$ Claims to external self-determination by a minority group are seen as posing a challenge to international law as well as to the liberal state and also to the wider community of states. ${ }^{43}$

Professor Dame Rosalyn Higgins suggests that the question of whether a minority group has a right of external self-determination requires understanding "the relationship between self-determination and national unity." ${ }^{44}$ Contemporary understandings of the normative content of selfdetermination after the decolonisation era have emphasised that there is no automatic right of a group to secede from the state. ${ }^{45}$

That self-determination poses no threat to the territorial integrity of the state is stressed in the 1970 Friendly Declaration. ${ }^{46}$ This instrument was produced towards the end of the era of decolonisation, perhaps prescient of the continuing importance that the principle would have in international law. The Declaration's inclusion of the principle consists of two components.

First, it employs the principle of territorial integrity as a limit to the scope of the right of self-determination. ${ }^{47}$ Thus, a racially or ethnically distinct group within a State, even if it qualifies as a peoples for the purposes of selfdetermination, does not have the right to unilateral secession simply because it wishes to create its own separate State. ${ }^{48}$ The prevailing view amongst States

${ }^{40}$ Ibid; see Declaration on the Granting of Independence to Colonial Territories and Peoples GA Res 1514 (XV). December 14, 1960. GAOR 15 ${ }^{\text {th }}$ Sess, Supp 16, 66.

${ }^{41}$ Higgins, above n 38, p 121.

${ }^{42}$ Vidmar, above $\mathrm{n} 30$, at 808.

${ }^{43}$ See discussion in section 5 below.

${ }^{44}$ Higgins, above n 38, p 121.

45 According to Higgins: "The evolving norms on self-determination contained undeniably and consistently - an anxious refrain whereby self-determination is to be harnessed to, and not the enemy of, territorial integrity." Higgins, above n 38, p 121.

46 According to the Friendly Relations Declaration: "Nothing in the foregoing paragraphs shall be construed as authorising or encouraging any action which would dismember or impair, totally or in part, the territorial integrity or political unity of sovereign and independent States conducting themselves in compliance with the principle of equal rights and self-determination of peoples as described above and thus possessed of a government representing the whole people belonging to the territory without distinction as to race, creed or colour."

${ }^{47}$ Vidmar, above n 30, at 808.

${ }^{48}$ Mancini, above n 32, at 556. 


\section{INDIGENOUS SELF-DETERMINATION}

is that the availability of such a right would reduce to nothing the territorial sovereignty and integrity of States and would lead to interminable conflicts and chaos, as evidenced by the dissolution of the former Federal Republic of Yugoslavia. There is no general right under international law or international practice which entitles any ethnically or racially distinct group within an existing state to claim a right to secede from the metropolitan state.

Secondly, however, the Friendly Declaration may be understood to suggest that under certain circumstances the territorial integrity limitation on the right of self-determination will not arise. ${ }^{49}$ Put another way, while selfdetermination should normally be enjoyed and exercised inside the existing framework of states, are there circumstances which would exceptionally legitimise secession? It is clear that the wish of a group to secede from the metropolitan state - whether to form their own independent state or to join another state - will be at its most intense where their human rights have been infringed and suppressed. ${ }^{50}$ Higgins is of the view that minorities do not have a "right" of self-determination and in effect have no "right" to secession. ${ }^{51}$

According to Professor James Crawford, however, the key consideration is how the minority group has been treated by the metropolitan state:

"The question is whether... a State that does not conduct itself in compliance with the principle of equal rights and self-determination of peoples; e.g., in the case of total denial to a particular group or people within the State any role in their own government, either through their own institutions or the general institutions of the state. At least it is arguable that, in extreme cases of oppression, international law allows remedial secession to discrete peoples within a State, and that the 'safeguard clause' in the Friendly Relations Declaration ... recognize this even if indirectly.",52

In 1998, the Supreme Court of Canada in the Reference Re Secession of Quebec case took the opportunity to address these implications. In particular, it considered whether "when a people is blocked from meaningful exercise of its right to self-determination internally, it is entitled, as a last resort, to exercise it by secession." ${ }^{53}$ The Court declared "international law expects that the right to self-determination will be exercised by the peoples within the

\footnotetext{
${ }^{49}$ Vidmar, above n 30 , at 808.

${ }^{50}$ Higgins, above n 38, p 124.

${ }^{51}$ Ibid, p 124.

52 J Crawford The Creation of States in International Law (Oxford: Oxford University Press 2006), p 118.

${ }^{53}$ Reference Re Secession of Quebec (1998) 115 ILR 536.
} 
framework of existing sovereign states and consistently with the maintenance of the territorial integrity of those states." ${ }^{54}$ The Court went on to say that the right of external self-determination, that is secession, "arises only in the most extreme of cases and, even then, under carefully defined circumstances".. 55

Antonio Cassese suggests somewhat controversially that such circumstances might be where the group in question is subject to "extreme and unremitting persecution" combined with the "lack of any reasonable prospect for reasonable challenge". ${ }^{56}$ The conclusion to be drawn from both international law and international practice is that there is little support for the application of self-determination as conferring the right of identifiable groups within a state to secede from a metropolitan state outside the colonial context. ${ }^{57}$

\section{STATE RESISTANCE TO INDIGENOUS RIGHTS}

If there is little to no real possibility of indigenous self-determination being exercised to secede from the state, just why it is that states raised objections to self-determination in the Declaration? In focusing on the positionality of the four states voting against approval of the Declaration ${ }^{58}$, this article argues that the state objection was not due to any actual fear of self-determination resulting in indigenous efforts to secede from the state. Rather, the objection was to self-determination as one of the class of "hard" 59 rights granted to a collective. ${ }^{60}$

States have exhibited an extreme response to the idea of indigenous selfdetermination - even though the likelihood of any feared threat of indigenous secession is thought to be nearly zero. The threat of secession is more of an imagined fear than a real and potential threat to state territorial integrity. It is not the thought of indigenous groups having some level of control over their own political and cultural affairs which states are reacting to when they express resistance to the notion of indigenous self-determination. States have

\footnotetext{
${ }^{54}$ Ibid, 582.

55 (1998) 115 ILR 536, 584.

${ }^{56}$ A Cassese Self-Determination of Peoples (Cambridge: Cambridge University Press 1995), p 120.

${ }^{57}$ Crawford, above n 52, p 127.

${ }^{58}$ Australia, Canada, New Zealand and the United States.

${ }^{59}$ See section 2 above.

${ }^{60}$ See generally S Lightfoot "Selective Endorsement without Intent to Implement: Indigenous Rights and the Anglosphere" (2012) 16(1) The International Journal of Human Rights 110.
} 


\section{INDIGENOUS SELF-DETERMINATION}

expressed similar although perhaps more muted concerns about concepts of indigenous autonomy and self-government. ${ }^{61}$

The close relationship between indigenous internal self-determination and autonomy is expressed in the final and approved version of the UNDRIP. Article 4 explains that autonomy is itself is an exercise of the right to selfdetermination. Article 4 provides that indigenous autonomy is granted in "internal and local affairs..." ${ }^{\prime 62}$ through an exercise of self-determination.

Some researchers have hypothesised that state resistance to any form of indigenous self-government, autonomy or self-determination is rooted in roots of state policies of assimilation. While these policies have largely been abandoned at least officially, it must be questioned whether the abandonment has reached levels of practice as opposed to official rhetoric. Notions of indigenous autonomy are at odds with assimilation and might be viewed by states as being a part of the state itself. ${ }^{63}$

This perceived rejection of the state may in turn fuel state rejection of self-determination, where indigenous self-determination is seen as being at odds and a threat to state identity as liberal state where individual rather than group autonomy is one of the core defining values. ${ }^{64}$ This is particularly true of the Jacobin form of liberal states where

"loyalty to the state and the so-called state-nation [is]... more important than loyalty to subgroups. The ideal of equality, also implies cultural equality, that is the eradication of all forms of cultural differentiation." 65

Thus, indigenous claims to rights to differentiate themselves from the state and simultaneously to call upon the state to promote and safeguard those rights causes a crisis of identity for Jacobin liberal states.

The threat to state identity is not only one of a perceived threat to territorial integrity, but of the spectre of a clearly distinct indigenous polity within the state boundaries that states must both ensure are included and yet are able to maintain their distinctness. ${ }^{66}$ Despite that potential threat, Daes observes:

\footnotetext{
${ }^{61}$ Ibid, Table 1, 117-118.

${ }^{62}$ Article 4, United Nations Declaration on the Rights of Indigenous Peoples.

${ }^{63}$ H Hannum "New Developments in Indigenous Rights" (1988) 28 Virginia Journal of International Law 649 at 657.

${ }^{64}$ See E Bornman "National Symbols and Nation Building in Post-Apartheid South Africa" (2006) 30 International Journal of Intercultural Relations 383.

${ }^{65}$ Ibid, at 386.

${ }^{66}$ See United Nations Declaration on the Rights of Indigenous Peoples, in particular Articles 2, 3, 4, 5, 8, 9, 16, 17, 19, 33 and 38 .
} 
"....although few governments are yet prepared to concede the right to self-determination to Indigenous Peoples, most of them have already accepted the subsidiary or substitute right of internal selfgovernment." ${ }^{67}$

Just what level of acceptance this "substitute" principle has been given is suspect, given the continued state resistance to a full domestic implementation of all of the UNDRIP. ${ }^{68}$ Yet Daes is at pains to explain that the form that indigenous autonomy would take is not the sort that would provide any real threat to even Jacobin liberal state identity.

"The goal is neither complete independence of Indigenous Peoples nor the kind of local autonomy which would lead to social or political isolation and continuing vulnerability of Indigenous Peoples. What most Indigenous Peoples seek, and the United Nations has so far endorsed, is a hybrid of autonomy. Indigenous Peoples must be able to participate effectively in the decision affecting their destiny at all levels, enjoying a large measure of control over their internal affairs, and in equitable sharing of power in national politics." $" 69$

Some measure of integration with the state is arguably then beneficial to indigenous groups, and as noted, the UNDRIP creates an obligation for states to ensure that indigenous individuals and groups are not isolated from the state. Lightfoot's chart ${ }^{70}$ again reveals the expression of state uneasiness with the concepts of internal self-government. This is demonstrated by the state stance that the UNDRIP is only aspirational and not binding, thus not evincing any requirements that the state actually do anything to enact the UNDRIP content. ${ }^{71}$ Alternatively there is insistence that the state's laws and policies are already in compliance with UNDRIP, again meaning that the state must not take any action to enact UNDRIP. ${ }^{72}$ To take action that gave credence to separate and distinct communities would be a threat to the Jacobin form of the liberal state. That would shift the state form to that of the syncretistic state where:

${ }^{67}$ E A Daes "The Concepts of Self-Determination and Autonomy of Indigenous Peoples in the Draft United Nations Declaration on the Rights of Indigenous Peoples" (2001) 14 St Thomas Law Review 259 at 269.

${ }^{68}$ See Lightfoot, above $\mathrm{n}$ 60, at 110.

${ }^{69}$ Daes, above $\mathrm{n} 67$, at 269. Emphasis in original.

${ }^{70}$ Lightfoot, above n 60, Table 1 at 117-118.

${ }^{71}$ Ibid.

${ }^{72}$ Lightfoot, above n 60, Table 1, at 117-118. 


\section{INDIGENOUS SELF-DETERMINATION}

“...ethnic, racial and other groupings [are] the building blocks of a larger unity and involves policies of multiculturalism that guarantee the cultural rights of ethnic or other minorities."73

State acceptance of indigenous rights is in itself not an either-or choice. It is not a simple matter of a state either rejecting or accepting rights. There are varying levels of acceptance and effectiveness that states give to any international norm within domestic law, policy and institutions. The varying levels of acceptance are referred to as "normative salience." Different scales measuring the level of normative salience have been developed, with one of the most detailed being that developed by Loren Cass. ${ }^{74}$ His eight level scale indicates state responses from explicit rejection of a norm to such acceptance that the norm has a "taken-for-granted" 75 quality within domestic institutions, law and policy. ${ }^{76}$

${ }^{73}$ Bornman, above n 64, at 386.

${ }^{74}$ L Cass The Failures of American and European Climate Policy: International Norms, Domestic Politics and Unachievable Commitments (State University of New York Press, Albany, 2006).

75 Ibid, p 10.

76 “1. Irrelevance: National leaders do not acknowledge the emergent international norm in any way, and it is not a part of the foreign or domestic policy dialogue. National leaders do not even feel compelled to justify actions that contravene the proposed norm.

“2. Rejection: National leaders acknowledge a proposed norm but reject it. The state will likely support an alternative norm and engage in debate with supporters of the less desirable alternative. The dialogue is conducted primarily on the international stage, and the normative debate has not entered mainstream domestic political dialogue.

"3. Domestic Relevance: National leaders continue to reject the proposed international norm, but it has entered the domestic political dialogue. At this point the government faces pressure from both international and domestic actors to affirm the emergent norm.

"4. Rhetorical Affirmation: National leaders affirm the international norm as a result of political pressure from within and/or internationally. The norm is now a part of the domestic and foreign policy dialogue, but it has not been translated into foreign or domestic policy changes.

“5. Foreign Policy Impact: National leaders adjust the state's foreign policy to affirm the norm and may support its inclusion in international agreements. The change in position may be the result of persuasion of the appropriateness of the emergent norm or through domestic and/or international coercion. However, national leaders continue 
The question arises as to why states are motivated to internalise international norms at any level. Scholars have offered very similar views as to why states adhere to international norms within their domestic institutions and laws. Given that international law is sometimes presented as an obligation voluntarily taken on by states, from that viewpoint it might seem reasonable to assume that states comply with international norms because they want to. But, in fact, it is not so simple as that. The conception of international law as a body of voluntary state members is contested. Other conceptions include the international community is one of power and politics, where in an age of globalisation, membership and a good reputation are necessary to receive favourable treatment in the international community across a range of activities from bank loans to trade arrangements. ${ }^{77}$ Accordingly, the factors that affect whether that states do- and do not - achieve high normative salience for any particular international norm are complex.

Alexander Wendt argues there are three reasons for states to adhere to international norms within their domestic laws and institutions: "because they are forced to, because it is in their self-interest, and because they perceive the norms to be legitimate."

to reject changes in domestic policy to implement the norm's behavioral imperatives, or domestic actors continue to reject the norm and block domestic changes required by the norm.

"6. Domestic Policy Impact: National leaders and other actors begin to justify changes in domestic policy on the basis of the international norm. At this point, the policy changes typically serve other purposes as well, but the norm provides additional justification for the changes. The norm is fully embedded in the domestic political dialogue, but the onus is still on the supporters of the norm to justify policy changes that may adversely affect domestic interest groups.

"7. Norm Prominence: Domestic interest groups that wish to continue policies or pursue new initiatives that contradict the norm must now justify the violation of the norm. The burden of proof has shifted and the norm is becoming embedded in the domestic institutional structures and policies of the state.

"8. Taken for Granted: The norm has become embedded in the domestic institutional structure of the state, and compliance with the norm is nearly automatic." Cass, above n 74, pp 9-10.

77 See O Hathaway "Between Power and Principle: An Integrated Theory of International Law" (2005) 72 University of Chicago Law Review 469, and in particular her discussion on "collateral benefits" for states in joining a human rights treaty at 474 at 507-511.

${ }^{78}$ A Wendt Social Theory of International Politics (Cambridge University Press, 1999) 250. 


\section{INDIGENOUS SELF-DETERMINATION}

This is consistent with the Cass scale, where different levels of normative salience are reached in response to political pressure, domestic and international advocacy, and the interest of the state. Many norms are given effect because a state determines that the norms are legitimate. ${ }^{79}$ Yet, as Wendt points out, not all norms are internalised by a state on the basis of being seen as legitimate. A state might internalise a norm that it views to be in conflict with its own values or identity, but does so because of political expedience (which Wendt expresses as in the self interest of the state) or through compulsion. State resistance to the norm of indigenous selfdetermination can be examined through understanding its place on the scale of normative salience and on state expressions for accepting or resisting the norm.

Cass points out: “... domestic institutional structures, political culture and historically contingent choices will be critical intervening variables in the translation of international norms into domestic policy." 80 A high level of salience cannot be achieved without these changes in not only laws, but domestic institution and policy as well. ${ }^{81}$ Provisions of the UNDRIP will not be effective unless given high salience at the domestic level - something that is highlighted in comments made by the current United Nations Special Rapporteur on indigenous issues, Professor James Anaya:

"For the Declaration to be fully operative, States must pursue a range of affirmative, special measures that engage the various institutions of law-making and public administration. This involves a complex process of legal and institutional reform, judicial action, specific policies, and special reparation procedures. It is a process that requires States' full political engagement and financial commitment, and which is not free from obstacles and difficulties of all sorts." 82

Real change within domestic institutions and policies has to occur in order to achieve that level of salience that gives effect and access to Declaration rights at the domestic level. ${ }^{83}$

79 J Brunee and S Toope "International Law and Constructivism: Elements of an Interactional Theory of International Law" (2000) 39 Columbia Journal of Transnational Law 20

${ }^{80}$ Ibid, p 2.

${ }^{81}$ Cass, above $\mathrm{n} 74$.

${ }^{82}$ A/HRC/9/9/9 (n 2) para 87. Emphasis added.

${ }^{83}$ Anaya's comment: "Implementing the Declaration will normally require or may be facilitated by the adoption of new laws or the amendment of existing legislation at the domestic level.... Also normally required will be new regulatory frameworks, which in most countries are still lacking or are insufficient. It is important to note that the 
Sheryl Lightfoot argues that states indorse indigenous rights for a variety of political reasons. Her research points to the changing positions of the four "no-states" which have all subsequently changed their opposition to the UNDRIP to one of at least rhetorical support. However, even in voicing support for the UNDRIP, all four of the states continue to express opposition to some of the rights within the UNDRIP, including its self-determination provisions, albeit those have been limited to internal self-determination and the ability of an indigenous group locating the right to secede from the state nullified by Article 46 of the UNDRIP. ${ }^{84}$ States are willing to endorse indigenous "soft rights" that there is a rejection of rights seen as "hard rights" "would threaten the liberal framework and the sovereignty status quo." 88 Lightfoot indicates that those norms which are seen by the state as threatening to liberal states are rejected, a view that is also given by Hale in his assessment of variance in state acceptance of some but rejection of other indigenous norms. ${ }^{89}$ Hale notes the indigenous norms which states are receptive to: "language, politics, spirituality, intellectual production and educational reform" ${ }^{90}$ Those rights that are compatible with the identity of a liberal state are endorsed - those that threaten it are rejected - and those that threaten it are invariably those that provide for "widespread collective empowerment." 91

Certainly, the right of self-determination, whether cast as internal or external, is within that class of rights that are both collective and empowering. Self-determination for indigenous groups is thus rejected and resisted by the state. The state sees the grant of self-determination as threatening to its very

legal and institutional transformations required by the Declaration are usually not sufficiently addressed by enacting specific "indigenous laws", as many States have done, but rather will normally also involve the transformation of broader legal structures in key areas. A/HRC/9/9 11 August 2008 Report of the Special Rapporteur on the situation of human rights and fundamental freedoms of indigenous people. Emphasis added.

${ }^{84}$ Article 46, UN Declaration on the Rights of Indigenous Peoples.

${ }^{85}$ Lightfoot, above n 10, at 103.

${ }^{86}$ Ibid.

${ }^{87}$ Ibid.

${ }^{88}$ Ibid.

${ }^{89}$ C Hale "Does Multiculturalism Menace? Governance, Cultural Rights and the Politics of Identity in Guatemala" (2002) 34 Journal of Latin American Studies 485 at 520.

${ }^{90}$ Ibid.

${ }^{91}$ Ibid. 


\section{INDIGENOUS SELF-DETERMINATION}

existence - not in terms of an actual secession of territory, but to its identity in liberalism, because the idea of collective rights is an anathema to the liberal nature of the state's existence, and collective rights which empower a group. That there is no real likelihood of an effort of an indigenous group to secede from the state, and that modern international law is not supportive of the existence of such a right, does not temper state resistance to the notion of indigenous self-determination. State resistance is not located in the fear of secession. The fear and resistance to indigenous self-determination is at a more abstract level, seen as a threat to the form and identity of the state itself due to the nature of the right - not that the right might ever be exercised.

\section{CONCLUSION}

As this analysis demonstrates, modern international law would provide little support for indigenous groups to exercise a right to secession from the metropolitan state. This is unlikely to be seen as a legitimate exercise of the right to external self-determination. The right to secede from the state is available in only limited circumstances. The right to even external selfdetermination does not carry with it an automatic right to secede from the state. But state resistance to indigenous self-determination in the UNDRIP was not grounded in a poor understanding of international law. It is difficult to fathom that all four "no-states" were misinformed on the international law's view on the very narrow circumstances in which a right to secede from the state can be exercised with approval and acceptance from the international community.

This raises a question as to why states positioned themselves in opposition to the provision of a right to self-determination to indigenous groups. Rather than a well-founded fear that indigenous groups would in fact exercise this to secede from metropolitan states, this is in fact reflective of the resistance that states have to a class of rights that they deem to be too empowering to indigenous groups and thus threatening to the relationship of state dominance and domestic control of indigenous groups. A move of indigenous rights from domestic to international rights threatens to displace states from a position of unchallenged control over indigenous groups and individuals within their borders. The displacement of the state may again be more symbolic than real, as the UNDRIP is heavily focused on state provision of rights to indigenous peoples, for all that it is a document of international law. But even to that end, state resistance demonstrates that there is a lack of real acceptance of the international law principles of self-determination and autonomy to replace the domestic principles, laws and policies of assimilation. State acceptance of indigenous rights is both reluctant and piecemeal. Accepting "hard rights" for 
indigenous groups and giving them a high level of salience within domestic frameworks would mean a wholesale change in state identity.

This means that the "no-state" resistance to an effective recognition of indigenous rights within their domestic frameworks is entrenched and will be difficult to overcome. An examination of state positionality on indigenous self-determination reveals that behind state rhetoric and explanation lays a much more complex set of reasons - reasons steeped in state identity and the view of indigenous rights as a threat to a liberal state identity.

Given that states view that highly salient indigenous rights pose a risk to state identity, it is unlikely that the stance that states have taken regarding indigenous self-determination will change. Only a reformation of state identity from Jacobin liberalism to a syncretistic form of multiculturalism is likely result in state acceptance of other than notional and aspiration rights for indigenous peoples. 